\title{
PENGGUNAAN MODEL PEMBELAJARAN TIPE STUDENT TEAM ACHIEVEMENT DIVISIONS DALAM MENINGKATKAN PRESTASI BELAJAR FISIKA UNTUK SISWA SMAN 4 TEBO
}

\author{
MARIANI \\ SMA Negeri 4 Kabupaten Tebo Provinsi Jambi \\ Email : mariani179@yahoo.com
}

\begin{abstract}
ABSTRAK
Penelitian ini bertujuan untuk mengetahui penggunaan model pembelajaran tipe Student Team Achievement Divisions (STAD) dalam meningkatkan prestasi belajar fisika untuk siswa SMA Negeri 4 Kabupaten Tebo Provinsi Jambi. Penelitian ini adalah Penelitian Tindakan Kelas (PTK) menggunakan model pembelajaran Kooperatif tipe STAD yang melalui 2 siklus, dimana tiap siklus meliputi kegiatan perencanaan, pelaksanaan tindakan, observasi, dan refleksi menurut metode Kemmis dan Taggart. Penelitian ini dilaksanakan pada bulan September 2019 dan Siklus II pada bulan November 2019. Subjek penelitian adalah siswa kelas XII MIPA 1 SMA Negeri 4 Tebo tahun pelajaran 2019/2020 yang berjumlah 34 siswa. Teknik pengumpulan data meliputi: Tes diagnostik, wawancara, pengamatan, dan catatan lapangan. Hasil penelitian menunjukkan bahwa penggunaan model pembelajaran kooperatif tipe STAD menunjukkan peningkatan prestasi belajar siswa dengan rata-rata hasil belajar sebelum perbaikan sebesar 47,65, setelah siklus I sebesar 68,53 dan mengalami peningkatan setelah siklus II sebesar 82,06. Begitu juga hasil pada tindakan siklus I untuk tingkat ketuntasan belajar siswa baru mencapai $23,53 \%$ dimana hanya 8 orang siswa dari 34 orang siswa yang mencapai nilai di atas 75 . Setelah dilakukan tindakan siklus II, tingkat ketuntasan belajar siswa menunjukan peningkatan menjadi $94,11 \%$ dan masih terdapat 2 orang siswa $(5,89 \%)$ yang tidak mencapai nilai di atas 75 .
\end{abstract}

Kata Kunci: metode pembelajaran tipe STAD, prestasi belajar, fisika.

\section{PENDAHULUAN}

Pendidikan Sains adalah upaya para pendidik/guru menggunakan hasil penelitian ilmiah dari para ilmuwan, untuk disesuaikan dengan perkembangan intelektual siswa. Sains yang dipelajari di sekolah diistilahkan dengan Sains Sekolah (school science). Sains Sekolah harus memiliki kedalaman yang berbeda antara jenjang masing-masing sekolah dan diolah secara pedagogik oleh guru. Sehingga Sais Sekolah merupakan hasil eksplanasi pedagogik (Herlanti, 2014). Adapun Fisika (sains) merupakan salah satu kajian yang selalu menarik untuk dikemukakan karena adanya perbedaan karakteristik khususnya antara hakikat dan hakikat fisika (sains). Sebagai pengetahuan, fisika (sains) mempunyai ciri khusus antara lain abstrak, deduktif, konsisten dan logis (Peranti, dkk, 2019).

Menurut Putri, dkk (2017) Keabstrakan fisika (sains) disebabkan oleh objek dasarnya yaitu fakta, konsep, operasi dan prinsipnya masih bersifat abstrak. Ciri khusus yang tidak sederhana menyebabkan fisika (sains) tidak mudah untuk dipelajari sehingga banyak siswa yang kurang tertarik untuk mempelajarinya. Hal ini memerlukan sarana yang dapat menjembatani keilmuan fisika (sains) sehingga tetap terjaga dan lebih mudah dipahami. Pencarian sarana tersebut merupakan tantangan bagi guru untuk memilih metode atau model pembelajaran yang lebih menarik mudah dipahami, menggugah semangat, menantang untuk terlibat, dan dapat menjadikan siswa lebih cerdas, namun tetap berusaha untuk mengurangi kesenjangan antara kemajuan pengetahuan di dunia dengan kondisi pendidikan di Indonesia, sehingga memudahkan untuk menyesuaikan pembelajaran dengan negara lain. Perkembangan dan kemajuan pembelajaran fisika (sains) di dunia tidak bisa diabaikan karena dapat menyebabkan kita semakin sulit mengejar kemajuan negara lain. Pembelajaran fisika (sains) adalah proses pemberian pengalaman belajar kepada siswa melalui serangkaian kegiatan yang terencana sehingga mereka memperoleh kompetensi tentang apa yang akan dipelajarinya (Asyhari, dkk, 2014). 


\section{STRATEGY : Jurnal Inovasi Strategi dan Model Pembelajaran Vol 1. No 2. Oktober Tahun 2021 e-ISSN : 2798-5466 P-ISSN : 2798-5725}

Terdapat beberapa tujuan pembelajaran fisika (sains) kepada siswa, diantaranya: (1) Memahami konsep fisika (sains), menjelaskan keterkaitan antara konsep dan mengaplikasikan konsep dalam pemecahan masalah, (2) Menggunakan penalaran pada pola dan sifatnya, memanipulasi fisika (sains) dalam membuat generalisasi, menyusun bukti atau menjelaskan gagasan dan pernyataan fisika (sains), (3) Pemecahan masalah yang meliputi kemampuan merancang metode penyelesaian dan menafsirkan solusi yang diperoleh, (4) Mengkomunikasikan gagasan dengan simpel, dan (5) Memiliki sikap menghargai kegunaan fisika (sains) dalam kehidupan yaitu memiliki rasa ingin tahu, perhatian dan minat dalam mempelajari fisika (sains), serta sikap ulet dan percaya diri dalam pemecahan masalah (Puspitasari, 2019).

Menurut Sulasmi (2019), pada dasarnya, faktor-faktor yang mempengaruhi prestasi belajar siswa dapat digolongkan menjadi dua, yaitu faktor eksternal dan faktor internal. Faktor eksternal adalah faktor yang berasal dari luar diri siswa, salah satu diantaranya adalah ketepatan guru dalam memilih metode atau model dalam kegiatan mengajar. Fathurrohman (2015) menjelaskan bahwa Model Pembelajaran yang baik adalah model yang mampu menghantarkan siswa mencapai tujuan pendidikan dan melatih kemampuan siswa dalam berbagai kegiatan. Sedangkan faktor internal adalah faktor yang berasal dari dalam diri siswa, salah satunya adalah motivasi belajar siswa. Andriani, dkk (2019) mengatakan bahwa siswa yang bermotivasi tinggi dalam belajar memungkinkan akan memperoleh prestasi belajar yang tinggi pula, artinya semakin tinggi motivasinya, semakin intensitas usaha dan upaya yang dilakukan, maka semakin tinggi prestasi belajar yang diperolehnya.

Permasalahan yang dihadapi saat ini yaitu menurunnya tingkat pemahaman siswa terhadap mata pelajaran fisika (sains). Salah satu penyebabnya adalah cara penyajian materi oleh guru yang kurang menarik. Hal ini sesuai dengan apa yang diungkapkan oleh Amin (2017) bahwa pembelajaran fisika (sains) di sekolah menengah selama ini kurang terkait dengan kehidupan sehari-hari siswa sehingga banyak yang tidak mengetahui manfaat mempelajari fisika (sains).

Kondisi di atas juga terjadi di SMA Negeri 4 Tebo kelas XII MIPA 1 tahun pelajaran 2019/2020. Berdasarkan hasil observasi dan wawancara dengan guru dan kepala sekolah SMA Negeri 4 Tebo, dapat disimpulkan bahwa masalah yang dihadapi adalah kurangnya pemahaman siswa terhadap mata pelajaran fisika (sains) terutama materi elektrostatika. Oleh karena itu, peneliti merumuskan 4 hal yang dapat mempengaruhi pemahaman siswa dalam mempelajari materi elektrostatika, yaitu: (1) Dari dalam diri siswa, (2) Siswa kurang memperhatikan materi yang diajarkan oleh guru, (3) Bahasa yang digunakan oleh guru kurang bermakna bagi siswa, (4) Kurang memanfaatkan media pembelajaran yang ada di sekelilingnya, (5) Model pembelajaran yang digunakan guru kurang merangsang minat belajar siswa. Permasalahan yang timbul dari dalam diri siswa disebabkan cara berpikir kelas XII masih berada pada tahap konkrit [6]. Hal ini terjadi karena guru kurang memperhatikan mereka dalam proses belajar mengajar. Sehingga hasil belajar fisika (sains) cukup rendah.

Penyebab lain rendahnya hasil belajar siswa adalah karena guru dalam mengajarkan pelajaran fisika (sains) masih menggunakan metode konvensional. Dimana guru mengarahkan untuk membentuk budaya menghapal. Guru hanya menggunakan metode ceramah yang menuntut siswa untuk mendengar, memperhatikan, dan mencatat penjelasannya. Bukan berfikir logis dan kritis sehingga siswa pasif dalam proses pembelajaran. Untuk mengatasi masalah tersebut di atas, maka peneliti menawarkan salah satu model pembelajaran yaitu model pembelajaran Kooperatif Tipe STAD (Student Team Achievement Devision) sebagai alternatif perbaikan pembelajaran dalam upaya meningkatkan prestasi belajar fisika (sains) siswa pada materi elektrostatika di SMA Negeri 4 Tebo Provinsi Jambi.

Dilihat dari kondisi ini, perlu penggunaan model pembelajaran STAD di kelas XII MIPA 1 SMA Negeri 4 Tebo karena materi elektrostatika bukan materi yang mudah. Diperlukan model pembelajaran untuk memahami cara penggunaan rumus yang ada pada materi elektrostatika. Oleh karena itu penggunaan model pembelajaran tipe STAD sangat tepat 
untuk siswa kelas XII SMA. Agar lebih memudahkan memahami sebaiknya dalam pembelajaran ini lebih menekankan pada pembelajaran kooperatif. Pembelajaran kooperatif merupakan model pembelajaran atas teori bahwa siswa akan lebih mudah menemukan dan memahami konsep-konsep yang sulit apabila mereka dapat saling mendiskusikan, masalahmasalah dengan temannya, yang menekankan pentingnya kerja sama (Sudarsana, 2018).

Menurut Fahmi (2013), kegiatan pembelajaran yang dilakukan guru seharusnya dapat memberikan rasa tenang dan nyaman pada siswa, sehingga mampu untuk memberikan daya ingat yang berkepanjangan pada siswa. Salah satu upaya guru untuk menerapkan pembelajaran fisika (sains) khususnya materi elektrostatika dengan menerapkan model pembelajaran yang efektif dan kreatif serta mampu membuat siswa berpikir analisis dan kritis. Cara yang dilakukan yakni menggunakan metode STAD. Dengan model tipe STAD, siswa akan lebih senang mengikuti pelajaran fisika (sains) karena model tipe STAD merangsang siswa aktif mengeluarkan ide-idenya, sehingga minat untuk belajar fisika (sains) semakin besar (wijaya, dkk, 2018). Selain itu dengan menggunakan model tipe STAD siswa akan cepat memahami konsep fisika (sains) yang sifatnya abstrak melalui benda-benda yang konkrit, dimana siswa dihadapkan langsung dengan benda-benda nyata yang sesuai dengan kehidupan mereka seharihari (Lubis, 2012).

Berdasarkan alasan-alasan di atas, peneliti berusaha melakukan suatu perbaikan pembelajaran yang dirancang melalui Penelitian Tindakan Kelas (PTK). Penelitian ini merupakan kerjasama (kolaborasi) yang dilakukan antara peneliti dengan guru kelas XII di SMA Negeri 4 Tebo. Penelitian ini bertujuan untuk meningkatkan prestasi belajar siswa dalam materi elektrostatika dengan menggunakan model pembelajaran kooperatif tipe STAD di kelas XII MIPA 1 SMA Negeri 4 Tebo tahun pelajaran 2019/2020.

\section{METODE PENELITIAN}

Penelitian ini adalah merupakan Penelitian Tindakan Kelas (PTK) dengan menerapkan model pembelajaran Kooperatif tipe STAD yang dilaksanakan di kelas XII MIPA 1 SMA Negeri 4 Tebo provinsi Jambi. Subjek dalam penelitian ini adalah siswa kelas XII MIPA 1 SMA Negeri 4 Tebo yang berjumlah 34 orang siswa. Penelitian dilaksanakan pada semester ganjil tahun pelajaran 2019/2020 yang melalui 2 siklus, yaitu: Siklus I pada bulan September 2019 dan Siklus II pada bulan November 2019. Faktor yang akan diselidiki yaitu faktor guru, siswa dan sumber belajar.

Tindakan dalam penelitian ini dilakukan menurut metode Kemmis dan Taggart dalam Wardani 2005) meliputi: kegiatan perencanaan, pelaksanaan tindakan, observasi, dan refleksi. Teknik pengumpulan data meliputi: tes untuk mengumpulkan informasi tentang pemahaman siswa terhadap materi elektrostatika, wawancara untuk menggali kesulitan siswa dalam memahami konsep elektrostatika, pengamatan, dan catatan lapangan untuk mengumpulkan halhal penting yang terjadi selama pembelajaran berlangsung. Kriteria yang digunakan untuk mengungkapkan kemampuan siswa sesuai dengan kriteria standar yang diungkapkan Nurkancana (1986) sebagai berikut: "Tingkat penguasaan 90\% - 100\% dikategorikan sangat tinggi, $80 \%$ - 89\% dikategorikan tinggi, 65\% - 79\% dikategorikan sedang, 55\% - 64\% dikategorikan rendah dan $0 \%$ - 54\% dikategorikan sangat rendah".

\section{HASIL DAN PEMBAHASAN}

Berdasarkan hasil penelitian yang dilaksanakan pada kelas XII MIPA 1 SMA Negeri 4 Tebo diperoleh hasil yang dapat dilihat pada tabel berikut ini, 
Tabel 1. Distribusi Frekuensi Sebelum Perbaikan

\begin{tabular}{lccc}
\hline No & $\begin{array}{c}\text { Nilai } \\
(\mathbf{S})\end{array}$ & $\begin{array}{c}\text { Frekuensi } \\
(\mathbf{F})\end{array}$ & S X F \\
\hline 1 & 100 & 0 & 0 \\
2 & 90 & 0 & 0 \\
3 & 80 & 0 & 0 \\
4 & 70 & 2 & 140 \\
5 & 60 & 5 & 300 \\
6 & 50 & 16 & 800 \\
7 & 40 & 5 & 200 \\
8 & 30 & 6 & 180 \\
9 & 20 & 0 & 0 \\
\hline \multicolumn{5}{c}{ Jumlah } & 34 & 1620 \\
\hline \multicolumn{5}{c}{ Rata-rata } \\
\hline
\end{tabular}

Tabel 2. Distribusi Frekuensi Siklus 1

\begin{tabular}{|c|c|c|c|}
\hline No & Nilai (S) & Frekuensi (F) & $\mathbf{S X ~ F}$ \\
\hline 1 & 100 & 0 & 0 \\
\hline 2 & 90 & 3 & 270 \\
\hline 3 & 80 & 5 & 400 \\
\hline 4 & 70 & 17 & 1190 \\
\hline 5 & 60 & 4 & 240 \\
\hline 6 & 50 & 3 & 152 \\
\hline 7 & 40 & 2 & 80 \\
\hline 8 & 30 & 0 & 0 \\
\hline \multirow[t]{3}{*}{9} & 20 & 0 & 0 \\
\hline & Jumlah & 34 & 23,30 \\
\hline & \multicolumn{2}{|c|}{ Rata-rata } & 68,53 \\
\hline
\end{tabular}

Berdasarkan tabel 1 dan 2 dapat dilihat peningkatan prestasi belajar siswa sebelum perbaikan sampai siklus I. Dimana nilai rata-rata siswa naik dari 47,65 menjadi 68,53 setelah diadakannya siklus I. Hal ini menunjukkan bahwa model Pembelajaran Kooperatif tipe STAD berpengaruh terhadap peningkatan prestasi belajar siswa.

Hasil refleksi pelaksanaan tindakan siklus I menunjukkan bahwa aspek penguasaan konsep (prestasi belajar) secara keseluruhan siswa telah mencapai KKM, namun peneliti menghendaki agar penguasaan konsep dapat mencapai $75 \%$. Sehingga peneliti akan melanjutkan tindakan sampai siklus II. Kelemahan yang masih tampak pada diri siswa meliputi motivasi belajar yang belum maksimal dan masih ada siswa yang belum menguasai dengan baik alur berdiskusi.

Belum maksimalnya penguasaan konsep diakibatkan oleh penggunaan model pembelajaran tipe STAD yang masih kurang intensif dilakukan oleh siswa dan perlu adanya bimbingan individual selama mengerjakan lembar kegiatan yang diberikan. Kelemahan yang terjadi juga disebabkan oleh pengelompokkan siswa yang belum merata karena masih terdapat kelompok dengan semua anggotanya berkemampuan rendah atau semua anggotanya berkemampuan tinggi. Oleh karena itu perlu adanya pengelompokkan siswa yang dilakukan dengan mengelompokkan siswa yang berkemampuan tinggi dan rendah pada setiap kelompok.

Secara keseluruhan, untuk dapat mengatasi masalah tersebut di atas perlu adanya variasi pembelajaran yang lebih menarik lagi dengan memberikan soal-soal penerapan yang 
menantang secara berkelompok. Soal tersebut dimaksudkan agar kemampuan siswa mengerjakan soal menjadi lebih baik dan diharapkan agar siswa menjadi tertarik dalam mengikuti proses belajar mengajar. Selain itu, guru dapat memberikan penghargaan bagi siswa yang dapat menjawab soal dengan benar dan tepat waktu.

Tabel 3. Distribusi Setelah Perbaikan Siklus II

\begin{tabular}{|c|c|c|c|}
\hline No & Nilai $(\mathbf{S})$ & Frekuensi $(\mathbf{F})$ & S X F \\
\hline 1 & 100 & 0 & 0 \\
\hline 2 & 90 & 9 & 810 \\
\hline 3 & 80 & 23 & 1840 \\
\hline 4 & 70 & 2 & 140 \\
\hline 5 & 60 & 0 & 0 \\
\hline 6 & 50 & 0 & 0 \\
\hline & Jumlah & 34 & 2790 \\
\hline \multicolumn{3}{|c|}{ Rata-rata } & 82,06 \\
\hline
\end{tabular}

Berdasarkan tabel 3 diperoleh nilai rata-rata 82,06. Hal ini menunjukkan bahwa hasil belajar fisika (sains) siswa kelas XII MIPA 1 SMA Negeri 4 Tebo mengalami peningkatan. Persentase ketuntasan pada siklus I sebesar $23,53 \%$ sedangkan pada siklus II persentase ketuntasan belajar menjadi 94,11\%.

Hasil refleksi menunjukkan bahwa tingkat prestasi belajar siswa secara keseluruhan telah berhasil mencapai KKM, dengan 94,11\% siswa telah mencapai nilai ketuntasan/keberhasilan, sedangkan 5,89 \% (2 orang siswa) belum tuntas. Pembelajaran model Kooperatif tipe STAD menyebabkan proses pembelajaran menjadi bermutu. Adanya model tersebut menyebabkan suasana belajar berlangsung menantang dan menyenangkan. Perbaikan pembelajaran yang dilaksanakan telah mengatasi masalah yang dapat menghambat perkembangan sikap negatif.

Pelaksanaan pembelajaran yang dilaksanakan sesuai dengan konteks siswa secara variatif dapat meningkatkan sikap positif dan penguasaan konsep secara individual. Prestasi belajar Ilmu Pengetahuan Alam meningkat dan telah mencapai indikator keberhasilan yang telah ditetapkan. Oleh karena itu, proses pembelajaran dengan menggunakan strategi melalui model pembelajaran Kooperatif Tipe STAD dapat meningkatkan prestasi belajar siswa pada mata pelajaran Fisika (sains).

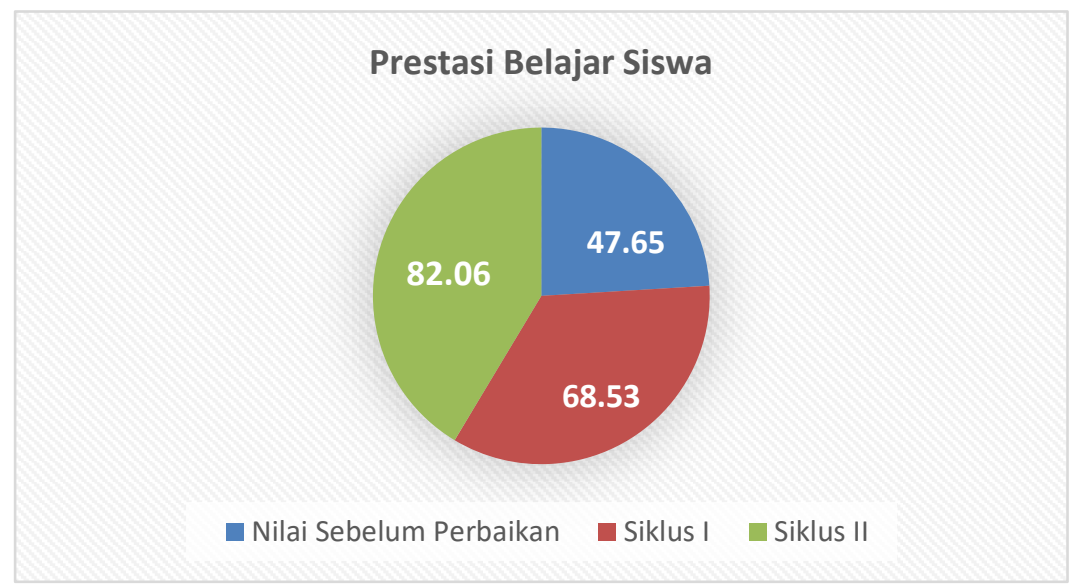

Gambar 1. Rata-rata Prestasi Belajar Siswa Sebelum Perbaikan, Siklus I \& Siklus II 
Tabel 4. Ketuntasan Belajar Siswa

\begin{tabular}{llr}
\hline No & & Ketuntasan Belajar \\
1 & Siklus I & $23,53 \%$ \\
2 & Siklus II & $94,11 \%$ \\
\hline
\end{tabular}

\section{KESIMPULAN}

Berdasarkan hasil analisis data dan temuan penelitian yang dilakukan maka dapat disimpulkan bahwa dengan menggunakan model pembelajaran Kooperatif Tipe Student Team Achievement Divisions (STAD) dapat meningkatkan pemahaman siswa terhadap konsep materi elektrostatika pada Kelas XII MIPA 1 SMA Negeri 4 Tebo tahun pelajaran 2019/2020. Hasil penelitian ditunjukkan dengan hasil pada temuan tindakan siklus I tingkat ketuntasan baru mencapai $23,53 \%$ dimana hanya 8 orang siswa dari 34 orang siswa yang mencapai nilai di atas 75. Setelah dilakukan tindakan siklus II, hasil belajar siswa menunjukan peningkatan menjadi $94,11 \%$ dan masih terdapat 2 orang siswa $(5,89 \%)$ yang tidak mencapai nilai di atas 75 . Adapun kenaikan prestasi belajar sebelum Siklus rata-rata sebesar 47.65, terjadi kenaikan pada Siklus I dengan rata-rata sebesar 68.53, dan pada Siklus II kenaikan rata-rata sebesar 82.06.

\section{DAFTAR PUSTAKA}

Amin, M. (2017). Sadar berprofesi guru sains, sadar literasi: Tantangan guru di abad 21. Research Report.

Andriani, R., \& Rasto, R. (2019). Motivasi belajar sebagai determinan hasil belajar siswa. Jurnal Pendidikan Manajemen Perkantoran (JPManper), 4(1), 80-86.

Asyhari, A. T., Sunarno, W. T., \& Sarwanto, S. (2014). Pengembangan perangkat pembelajaran fisika SMA berbasis inkuiri terbimbing terintegrasi pendidikan karakter. INKUIRI: Jurnal Pendidikan IPA, 3(01).

Fahmi, Z. (2013). Indikator pembelajaran aktif dalam konteks Pengimplementasian pendekatan pembelajaran aktif, kreatif, Efektif, dan menyenangkan (PAKEM). Al-Ta lim Journal, 20(1), 278-284.

Fathurrohman, M. (2015). Model-Model Pembelajaran. Jogjakarta: Ar-Ruzz Media.

Herlanti, Y. (2014). Tanya Jawab Seputar Penelitian Pendidikan Sains: Jawaban atas pertanyaan-pertanyaan mahasiswa tingkat akhir yang sering muncul dalam penelitian pendidikan sains. Yanti Herlanti.

Nurkancana. (1986). Evaluasi Pendidikan. Surabaya: Usaha Nasional.

Lubis, A. (2012). Pengaruh Model Pembelajaran Kooperatif Tipe STAD Terhadap Hasil Belajar Fisika Siswa Pada Materi Pokok Gerak Lurus di Kelas X SMA Swasta UISU Medan. Jurnal Pendidikan Fisika, 1(1), 27-32.

Peranti, P., Purwanto, A., \& Risdianto, E. (2019). Pengembangan Media Pembelajaran Permainan Mofin (Monopoli Fisika Sains) Pada Siswa Sma Kelas X. Jurnal Kumparan Fisika, 2(1 April), 41-48.

Puspitasari, A. D. (2019). Penerapan Media Pembelajaran Fisika Menggunakan Modul Cetak dan Modul Elektronik pada Siswa SMA. Jurnal Pendidikan Fisika, 7(1), 17-25.

Putri, R. F., \& Jumadi, J. (2017). Kemampuan guru fisika dalam menerapkan model-model pembelajaran pada Kurikulum 2013 serta kendala-kendala yang dihadapi. Jurnal Inovasi Pendidikan IPA, 3(2), 201-211.

Sudarsana, I. K. (2018). Pengaruh model pembelajaran kooperatif terhadap peningkatan mutu hasil belajar siswa. Jurnal Penjaminan Mutu, 4(1), 20-31.

Sulasmi, E. (2019). Analisis Faktor-Faktor Yang Mempengaruhi Prestasi Belajar Siswa Ditinjau Dari Aspek Manajemen Belajar Siswa (Studi Pada Siswa SMP Gajah Mada Medan). Jurnal Manajemen Pendidikan Dasar, Menengah dan Tinggi [JMPDMT], 1(1).

Wardani, dkk. (2005). Penelitian Tindakan kelas: Jakarta: Pusat Penerbit Universitas Terbuka. 
Wijaya, H., \& Arismunandar, A. (2018). Pengembangan Model Pembelajaran Kooperatif Tipe STAD Berbasis Media Sosial. Jurnal Jaffray, 16(2), 175-196. 